DOI http://dx.doi.org/10.18551/rjoas.2016-03.04

\title{
FACTORS INFLUENCING LOAN REPAYMENT BY CREDIT BENEFICIARIES OF MICROFINANCE INSTITUTIONS IN THE FAR NORTH REGION, CAMEROON
}

\author{
Achille Jean Jaza Folefack*, Josephine Sandrine Mahbou Teguia \\ Department of Agricultural Economics, University of Dschang, Cameroon \\ *E-mail: ajazafol@yahoo.fr
}

\begin{abstract}
In the Extreme North Region of Cameroon, the non-performing loans increased continuously by $17.5 \%$, as the number of banks in the financial sector facing insolvency continued rising. Hence, the present study is carried out to understand how members of microfinance institutions (MFIs) cope with the credit they are awarded in this region. Using questionnaire addressed to 201 members of MFls (comprised of 107 non-defaulters and 94 defaulters), the descriptive statistics and logit model are used in order to analyze the factors affecting the loan repayment capacity of credit beneficiaries in the MFIs. The results indicate that, members with small household size, with profitable activities, less distant from cash desks, trained for credit management, not married/single, and who use their credit for farming activities are more likely to refund their credit on time. These six factors show significant coefficients in the logit model. However, the six other factors such as the age, gender, farm size, source of finance, loan size, and use of improved technology show insignificant coefficients in the logit model, proving that they have less impact on the defaulter rate of credit beneficiaries. We therefore recommend to the government authorities to give much attention to the significant factors, if microfinance services need to be improved in this region.
\end{abstract}

\section{KEY WORDS}

Credit, logit model, microfinance institutions, defaulters, non-defaulters.

The movement of microfinance institutions (MFIs) in Cameroon has its roots in the 1960s through the creation of the first cooperative in 1963 (Muluh, 1995). Since then, the microfinance sector has greatly evolved and currently counts 438 establishments with 1,000 branches spread across the country. Among all these cash desks, 178 belong to the biggest network of MFIs, such as the Cameroon Cooperative Credit Union League (CAMCCUL), while 187 are independent institutions.

Cameroon counts 20 million inhabitants, with 2.5 million people affiliated to financial institutions, of which 1 million treat with classic banks and 1.5 million with MFIs. This represents a banking rate of over 10\% (World Bank, 2015). About $70 \%$ of the country's population lives in rural areas with agriculture being their main occupation. Hence, these MFIs act as source of funds to most farmers willing to invest in farming and other related activities. More than $30 \%$ of the Cameroonian rural population living below the poverty line, the microcredit loans help these poor people to be involved in income generating activities that allow them to accumulate capital and improve their standard of living. Hence, the increasing number of MFIs over the years in the country significantly helped to alleviate the poverty in rural areas (World Bank, 2015; Teguia, 2015).

However, for several years, the MFIs in the country have faced a number of challenges such as financial scandals related to poor governance in some institutions, embezzlement, lack of resources or administrative incivility which challenge the viability of the sector. Failure by farmers to repay their loans on time or not to repay them at all has become a serious problem facing both agricultural credit institutions and smallholder farmers. These difficulties are often the causes of failure of many MFIs in the country.

The increase in default rate is one of the major problems of lending institutions in Cameroon (Singh et al., 1985). Between 2009 and 2011, loans that financed the country's economy increased from 170 to 231 billion francs CFA (about 259 to 352 million of Euros). 
But during the same period, the non-performing loans increased continuously by $17.5 \%$, as the number of banks in the financial sector facing insolvency continued rising (IMF, 2012).

Loan default is a tragedy because failing to implement appropriate lending strategies and credible loan policies often result in demise of MFls (Hunte, 1996). Because of the high default rate (17.5\%) of credit beneficiaries, some Cameroonian MFIs have closed while others reviewed their criteria of granting credit in such a way that, access to credit becomes a severe problem faced by small farm holders. As a matter of fact, low repayment performance discourages the lender to promote and extend credit to large and fragmented farm households. Therefore, a thorough investigation of the various causes of loan default is of great importance both for policy makers and lending institutions. Hence, this study is undertaken in order to analyze the determinants of the repayment capacity of credit granted by MFIs to its members at the Far North Region of Cameroon.

\section{MATERIALS AND METHODS}

Study area and data collection. The field survey was carried out in Cameroon in August 2014. It was undertaken in the Far North Region, precisely in Maroua and its nearest surroundings departments (Diamaré, Mayo-Kani and Mayo-Sava). This area was chosen because the loan default rate is higher in this region (up to $57.4 \%$ ) as compared to a national average of $17.5 \%$ (IMF, 2012).

In this region, the multistage and purposive sampling techniques were used to select a total of 201 respondents who are customers of seven cash desks of MFIs (Tokombéré, Garey-Kaélé, Gakle, Palbara, Gayak, Bala and Sérawa). All the selected respondents practice agriculture as main activity. They comprised of 107 non-defaulters and 94 defaulters of credit beneficiaries. The non-defaulters were members of cash desks who always refund their credit on time whereas the defaulters were cash desks' members who refund their credit with many difficulties (either late or not at all). Using a prepared questionnaire and interview schedule, cross-sectional primary data were collected from the two categories of costumers (defaulters and non-defaulters) who received credit at least once between 2011 and 2014.

The data collected from each respondent were precisely the: credit repayment capacity (whether he is a non-defaulter or defaulter member), age, gender, marital status, training for credit management, household size, profit earned, farm size, secondary sources of finance, access to improved technology, loan size, type of activity financed, distance from cask desk, etc.

Data analysis. In this study, in order to analyze the factors influencing the loan repayment capacity by customers of MFIs in the Far North Region (Cameroon), the logit model is more convenient because the dependant variable is qualitative in nature, the explanatory variables are a mix of continuous and qualitative variables, and the sample size is low ( $N=201$ ) (Gujarati, 1995; Terrell, 1999; Wooldridge, 2009).

The logit model is used to predict the logit of the probability of the occurrence of the event, that is, the natural log of the odds ratio of having made one or the other decision (repayment or non-repayment of loans). By denoting $\mathrm{P}$ as the probability of making such decision from the predictors ${ }^{1} X_{1}$ to $X_{12}$, the mathematical formulation of the logit model used in this study is expressed in equation (1) such as:

$$
Y=\operatorname{Logit}(P)=\operatorname{Ln}\left(\frac{P}{1-P}\right)=\alpha+\beta_{1} X_{1}+\beta_{2} X_{2}+\ldots \ldots \ldots \ldots \ldots+\beta_{12} X_{12}
$$

where: $\mathbf{P}$ : is the predicted probability of the occurrence of event (credit repayment capacity); 1-P: is the predicted probability of non-occurrence of event (non-repayment capacity of credit); $\mathbf{Y}$ : member group (coded as $1=$ non-defaulter, $0=$ defaulter); $\mathbf{X}_{\mathbf{1}}$ : age of member (in years); $\mathbf{X}_{2}$ : gender of member (coded as $1=$ male, $0=$ female); $\mathbf{X}_{3}$ : marital status (coded as: $1=$ married; $0=$ non-married); $\mathbf{X}_{4}$ : trained for credit management (coded as $1=y e s$;

${ }^{1}$ Explanatory variables $=$ Predictors in logit model=Factors affecting the loan repayment capacity by MFIs' members. 
$0=$ no); $\mathbf{X}_{5}$ : household size (in number of persons); $\mathbf{X}_{6}$ : profit earned by member (in FCFA/ha); $\mathbf{X}_{\mathbf{7}}$ : farm size (ha); $\mathbf{X}_{\mathbf{8}}$ : secondary sources of finance (1=loan-only; $0=0$ others); $\mathbf{X}_{\mathbf{9}}$ : access to improved technology ( $1=y e s, 0=n o) ; \mathbf{X}_{10}$ : loan size (in FCFA); $\mathbf{X}_{11}$ : type of activity financed ( 1 =farming enterprise, $0=$ non-farming enterprise); $\mathbf{X}_{12}$ : distance from cask desk (in meters).

This study uses the SPSS software program (version 21.0) in order to estimate the descriptive statistics of all variables as well as the coefficients from equation (1) such as: $\boldsymbol{\beta}_{1}$, $\boldsymbol{\beta}_{2}, \ldots \ldots, \boldsymbol{\beta}_{12}$ (termed as $\boldsymbol{\beta}_{\mathrm{k}}$ ) which are respectively the slope coefficients of the explanatory variables $\mathbf{X}_{1}, \mathbf{X}_{2}, \ldots \ldots, \mathbf{X}_{12}$ (termed as $\mathbf{X}_{\mathbf{k}}$ ); and $\boldsymbol{\alpha}$ : intercept term.

The exponentials $\operatorname{Exp}(B)$ of the slope coefficients $\beta_{k}$ associated to the explanatory variables are interpreted as the Odds Ratio (OR) of the occurrence of the event ${ }^{2}$ (credit repayment capacity) for each increase in the predictor. A positive $\beta_{k}$ coefficient generally displays an OR greater than one $(O R>1)$ whereas a negative $\beta_{k}$ coefficient usually indicates an OR lower than one $(\mathrm{OR}<1)$. Usually, the expression $1 / \operatorname{Exp}(\mathrm{B})$ designates the inverse $\mathrm{OR}$ which is computed in order to facilitate the interpretation of the variables with negative coefficients (Gujarati, 1995; Terrell, 1999; Wooldridge, 2009).

\section{RESULTS AND DISCUSSION}

Descriptive field survey findings. The field survey results in Table 1 show that, $47.77 \%$ of respondents are defaulters whereas $53.23 \%$ of them are non-defaulters members of MFIs. The majority of respondents belong to the age group ranging between $31-40$ years i.e. $31.3 \%$ in relative terms (Table 1). This is the most active age for most members of MFls who reach the maturity, are courageous, strong enough, motivated, dynamic and more likely to invest at that age. We also realized that, most people of this age group hold high positions of responsibilities rendering them very active. Therefore, they greatly need the services offered by MFIs for their various activities to be successful. The lowest proportions of respondents $(4.5 \%$ and $14.9 \%)$ fall in the ranges of young people ( $<25$ and $25-30$ years old, respectively). These are young and non-mature people who are unable to borrow or manage money from MFIs (Table 1). In general, young people from these age groups have little charges and consequently have less need for financial services. Our results are similar with those obtained by Mingoas et al. (2014) who found out that, more than $59 \%$ of the farmers requesting credit from MFls are between 26 and 45 years old.

Table 1 results also show that, $68.5 \%$ of the respondents are male and $31.5 \%$ of them are female. This could be explained by the fact that, men generally have high financial charges as compared to women. Most of the time, male persons would need funds from MFIs in order to invest in various projects which they think would be gainful so as to enable them to afford the highest family charges (school fees, illnesses, marriage, building construction, etc). This is not the case for female persons who need money mainly for their dressing and the feeding of the family.

Concerning the marital status, $91 \%$ of respondents are married (either as monogamous or polygamous). This is not a surprising result at the Far North Region as people from this area get married very early (most of the time before the age of 23 years) (Ministry of Plan, 2015). The divorce persons are least represented with a proportion of $1 \%$. However, the widows represent $5.5 \%$ of respondents (Table 1 ). Having lost their spouses, the widow people most of the time have to face with several responsibilities; so it is normal that they turn out in search of financial support from MFIs. That is why they occupy the second position after married people. Finally, the single persons represent just $2.5 \%$ of the respondents. It is obvious that those who remain single need very little financial support, because they have little responsibilities. These results are in accordance with those obtained by Mingoas et al. (2014) who found out that, $63 \%$ of cattle breeders in the Far North Region (Cameroon) are married.

\footnotetext{
${ }^{2}$ Odds=Number of cases the event occurs, divided by the number of cases in which the event does not occur. Hence, the odds in this paper are interpreted as the chance of loan repayment by any MFIs' member.
} 
Table 1 - Socio-demographic characteristics of selected beneficiaries of credit granted by microfinance institutions in the Far North Region, Cameroon ( $\mathrm{N}=201)$

\begin{tabular}{|c|c|c|c|}
\hline Factor/variable & Categories & Freq./Mean & $\begin{array}{c}\text { Percentage } \\
(\%)\end{array}$ \\
\hline \multirow{2}{*}{ Member group* } & Non-defaulters & 107 & 53.23 \\
\hline & Defaulters & 94 & 46.77 \\
\hline \multirow{5}{*}{ Age of member* (years) } & $<25$ & 9 & 4.50 \\
\hline & $25-30$ & 30 & 14.90 \\
\hline & $31-40$ & 63 & 31.30 \\
\hline & $41-50$ & 53 & 26.40 \\
\hline & $>50$ & 46 & 22.90 \\
\hline \multirow{2}{*}{ Gender of member* } & Male & 138 & 68.50 \\
\hline & Female & 63 & 31.50 \\
\hline \multirow{4}{*}{ Marital status* } & Married & 181 & 91.00 \\
\hline & Single & 5 & 2.50 \\
\hline & Widow & 11 & 5.50 \\
\hline & Divorced & 2 & 1.00 \\
\hline \multirow{4}{*}{ Level of education* } & Illiterate & 88 & 44.30 \\
\hline & Primary school & 58 & 29.10 \\
\hline & Secondary school & 51 & 25.60 \\
\hline & University & 2 & 1.00 \\
\hline Household size $^{* *}$ (number of persons) & $/ /$ & 4 & $/ /$ \\
\hline \multirow{2}{*}{ Profit earned by member ${ }^{\star \star}($ FCFA) } & Non defaulters & $1,060,000$ & $/ /$ \\
\hline & Defaulters & 693,000 & $/ /$ \\
\hline Farm size ${ }^{* *}(\mathrm{ha})$ & $/ /$ & 1.21 & $/ /$ \\
\hline \multirow{2}{*}{ Sources of finance* (FCFA) } & Loan-only & 49 & 24.40 \\
\hline & Others & 152 & 75.60 \\
\hline \multirow{2}{*}{ Access to improved technology* } & Yes & 29 & 14.43 \\
\hline & No & 172 & 85.57 \\
\hline Loan size $^{* *}($ FCFA $)$ & $/ /$ & 142,662 & // \\
\hline \multirow{4}{*}{ Type of activity financed* } & Agriculture & 99 & 49.00 \\
\hline & Commerce & 46 & 22.90 \\
\hline & Livestock rearing & 40 & 19.90 \\
\hline & Social & 16 & 8.20 \\
\hline Distance from cash desk ${ }^{* *}$ (meters) & $/ /$ & 696.86 & $/ /$ \\
\hline
\end{tabular}

Notes: *: Frequency (Freq.) **: Mean

The educational level of credit beneficiaries is generally very low as proved by the very high level of illiteracy of interviewed respondents (44.3\%). Most people are illiterate because they come from poor families where parents are unable to send their children at school. They do not want their children to be illiterate like them and therefore count mostly on the credit granted by MFIs to send their children to school (because the school fees and furniture are very expensive to them). About $29.1 \%$ and $25.6 \%$ of respondents attended respectively the primary and secondary education with $1 \%$ of them who reach the university level (Table 1$)$. This latter group of respondents is less representative because they are relatively rich enough to afford the family needs and school fees for their children; so they have less pressure to borrow credit from MFIs. Our results are in concordance with Mingoas et al. (2014) who found out that, people borrowing money from MFIs are mostly illiterate. Most educated persons prefer to borrow money from classic commercial banks (Mingoas et al., 2014).

The findings in Table 1 also show the profit earned by members who received credit from MFIs. On the category basis, the non-defaulters earn the highest profit $(1,060,000$ FCFA/year) while the defaulters record the lowest returns (693,000 FCFA/year). As a matter of fact, the defaulter members justify the non-repayment of their loan by the very small amount of credit they received. They believe that the size of loan granted is insufficient to enable them to improve their living standard and repay the loan on time. On the other hand, the loan amount received by members, non-defaulters can be seen as sufficient since they are capable of meeting their needs and repaying their loan at time. Nevertheless, this latter 
category still requires higher credit amount than they receive because they intend to diversify or increase the size of their activities.

As sources of finance, Table 1 results also indicate that $24.4 \%$ of respondents depend only on the loan granted by MFIs in order to finance their activities. The remaining $75.6 \%$ depend on savings, and other informal sources such as njangui, family helps and grants for their investment (Table 1). As regards to the type of activities financed, $49 \%$ of the loans offered to respondents are used for agricultural practices, followed by commerce with $22.9 \%$ and lastly by livestock rearing and social activities representing $19.9 \%$ and $8.2 \%$, respectively (Table 1). The fact that most cash desks' members live in rural areas could justify why they also tend to invest their money mainly for farming purposes (World Bank, 2015).

Table 1 shows that, the farm size to practice agriculture averages 1.21 ha for all respondents i.e. lower than the mean of 1.8 ha characterizing agricultural exploitations in Cameroon. People from the Far North Region practice an extensive agriculture by using archaic rather than modern techniques of production. According to the Ministry of Plan (2015), most farmers in this zone tend to improve their production by extending the land area rather than improving the techniques of production. In Table 1, the use of improved technology is still very low (14.43\%) probably because of the low mechanization rate of agriculture in this region.

Table 1 indicates that the loan size is 142,666 FCFA on average per member. We can see from this result that, the loan amount received by members is very small and therefore may not favor easy repayment. In general, the members are given on average 9 months 3 weeks to refund/pay back their loan in all cask desks (Teguia, 2015). This very short deadline combined to the small loan size could justify the high default rate in the Far North Region. The short period of repayment greatly affects the decisions taken by members of cash desks because they believe they do not have enough time to invest the money they receive and as such have very limited chance of repaying the loan on time while maintaining their living standard. This length of repayment greatly impacts those members who take loans for livestock rearing, because they do not have enough time to breed/feed the animals. In the case of agriculture, the farmers have no time to recover their money in case they register poor production (Teguia, 2015).

Table 1 indicates that, the average distance between the cash desk and household is $0.69 \mathrm{~km}$, implying that the majority of members are close to their cash desks. Generally, the credit beneficiaries are bound to live around their cash desks in order to facilitate communication between members (Teguia, 2015).

Results and discussion from the estimated logit model. Table 2 shows the logit model results for analyzing the factors influencing the loan repayment by members of MFIs in the Far North Region, Cameroon. The overall goodness-of-fit measured by the significance of the Chi-Square statistic in the Omnibus test of model coefficients is high $\left(\chi^{2}=46.129\right.$, significant at $1 \%$ level). The percentage of model's correct prediction is reasonably good $(72.2 \%)$. The Hosmer and Lemeshow test shows that the model adequately fits the data (the test was not significant at $5 \%$ level with $p$-value $=0.299$, thus, the null hypothesis could not be rejected). In general, the coefficients of most of the explanatory variables show the expected signs (Table 2).

The econometric results of Table 2 show that, the household size of members is significant (at $5 \%$ level) and has a negative effect on the likelihood of loan repayment. The inverse of the odds ratio for this variable $[1 / \operatorname{Exp}(B)=1.108]$ indicate that, holding everything else constant, the probability that members repay their loan is 1.108 times higher for small households than larger ones.

The profit earned is positively associated with the repayment capacity of member, at a statistical significance level of $10 \%$ (Table 2). Profit is not risky, since the odds for the members with low profit are the same as those with higher profits (OR equal to one for this variable). This result can be explained by the fact that, all enterprises are profitable therefore indicating their capacities to repay their loans even if they have little or large profits. Our 
findings coincide with those of Onyeagocha et al. (2012) and Teguia (2015) who proved that, difficulties in repayment arose whenever a business was found to be unprofitable.

The distance between the member's home and the cash desk of MFIs has a positive impact on the repayment capacity of members. This variable is significant at $1 \%$ level and the probability of registering a default case is $99 \%$ for each additional meter in distance between the member's home and cash desk (Table 2). Thus confirming previous results by Nzongang et al. (2012) according to which, the nearer a person is to the MFIs, the less likely he is to default.

Table 2 - Logit estimate of determinants of loan repayment by credit beneficiaries of microfinance institutions in the Far North Region, Cameroon ( $\mathrm{N}=201)$

\begin{tabular}{lcccc}
\hline \multicolumn{1}{c}{ Explanatory variables } & $\beta$ & Sig. & $\operatorname{Exp}(\beta)$ & $1 / \operatorname{Exp}(\beta)$ \\
\hline Age of member (years) & 0.169 & 0.305 & 1.184 & $/ /$ \\
Gender of member (1/0) & -0.348 & 0.393 & 0.706 & 1.416 \\
Marital status (1/0) & 0.892 & $0.036^{* *}$ & 2.241 & $/ /$ \\
Trained for credit management (1/0) & 0.825 & $0.023^{\star *}$ & 2.283 & $/ /$ \\
Household size (number of persons) & -0.103 & $0.013^{* *}$ & 0.902 & 1.108 \\
Profit earned by member (FCFA/ha) & 0.000 & $0.052^{*}$ & 1.000 & $/ /$ \\
Farm size (ha) & 0.018 & 0.327 & 1.018 & $/ /$ \\
Sources of finance (1/0) & 0.268 & 0.511 & 1.308 & $/ /$ \\
Access to improved technology (1/0) & 0.408 & 0.254 & 1.504 & $/ /$ \\
Loan size (FCFA) & 0.000 & 0.835 & 1.000 & $/ /$ \\
Type of activity financed (1/0) & 0.816 & $0.025^{\star *}$ & 2.262 & $/ /$ \\
Distance from cash desk (meters) & 0.000 & $0.000^{\star * *}$ & 0.999 & $/ /$ \\
\hline
\end{tabular}

***: Significant at 1\% **: Significant at $5 \%$ *: Significant at $10 \%-2$ Log likelihood $=226.719$ Nagelkerke $R^{2}=0.278$ Percentage of correct prediction $=72.2 \%$

Omnibus Test of Model Coefficients: $\chi^{2}=46.129^{* * *}$ Hosmer and Lemeshow Test: $\chi^{2}=9.531$

Moreover, the risk of non-defaulting for members who have been trained on credit management is a little over twice $[\operatorname{Exp}(B)=2.229]$ as great as in the case of non-trained members (Table 2). This result is in light to a previous study of Onyeagocha et al. (2012) who found that borrowers who were trained on credit management are less likely to default than those who were not trained. This is because they are trained on how to implement their projects and manage the credit they receive proportionately.

As proved by its significant coefficient (at $5 \%$ level), the marital status equally has great influence on the repayment capacity of members such that, married, widows, separated and divorced members are 2.441 times more likely to default than members who are still single (Table 2). This result can be explained by the fact that, this category of members (married, widows, separated and divorced) generally has large family and consequently has more persons to take care. This result is in line with a previous study by Nzongang et al. (2012) who found that, a married woman is less likely to repay her loan than a single woman.

Besides, the type of activity financed represents for MFIs an important decisive factor of the repayment capacity of its members, in view of the $5 \%$ significance level of this variable $(p=0.025)$. Table 2 results indicate that, members who receive loans for agricultural purposes are 2.274 times more likely to repay them back than members who receive credit for other purposes. This can be explained by the fact that, farmers and livestock breeders take very high precautions because they are aware of the fact that their activity is very risky (e.g. subject to sunshine, rainfall, weather and various nature uncertainties). In addition of having their loans to return, they equally depend on these activities to survive. These results are contrary to those obtained by Nzongang et al. (2012) who concluded that, loan granted for activities other than agriculture, were less likely to default. This could be because, the study of Nzongang et al. (2012) was conducted in the city/urban area where agriculture is less important whereas our study mainly takes place in villages/rural areas where more than $70 \%$ people depend on farming activities to sustain their livelihood.

In contrast, being female member promotes the loan repayment at a substantial rate $[\operatorname{Exp}(B)=1.267]$, even though the variable remains insignificant (Table 2). These findings supports the results obtained by Hossain (1988) who reports that in Bangladesh, $81 \%$ of 
women encountered no repayment problems compared to $74 \%$ of men, but remains in line with Bhatt and Tang (2002) who found out that gender was not a significant determinant of loan repayment.

Although the farm size shows an insignificant coefficient, one can see that, a one unit increase in the farm size increases the member's likelihood to repay his loan on time by 1.018 (Table 2). This result confirms the findings from Awunyo (2012) who concluded that, an increase in the size of the farm decreases the probability of repayment default of farmer.

Although the coefficient of sources of finance is not significant, this variable has a positive influence on the loan repayment capacity of credit beneficiaries such that MFIs' members with several sources of finance are 1.308 times more likely to repay their loans than those with only one source (Table 2). Our results support the findings of Nzongang et al. (2012) who found out that the greater the sources of finance, the less likely the probability to default.

Loan size has no significant influence on the repayment capacity of members. Considering the fact that it has its odds ratio $[\operatorname{Exp}(B)]$ equal to one, it implies that the size of loan given to members has no impact on the capacity to repay. These results are contrary to those of Nzongang et al. (2012) who found out that the higher the amount of loan, the more likely a person is to default, but in line with results of Teguia (2015) who found out that the higher the amount received, the more likely the person is to repay. They are equally contrary to those of Jimenez and Saurina (2004) who reveal that increasing the amount of loan offered to the farmers by one Ghana cedis decreases the likelihood of loan repayment default by 0.26 .

Furthermore, the access to improved technology is not significant and its odds ratio [Exp(B)] of 1.504 indicate that, members who use improved technology are $50.4 \%$ less likely to encounter defaults. Our results also corroborate with the findings from Nzongang et al. (2012) who also draw similar conclusion as regards to whether the member uses credit to purchase a modern equipment necessary for its investment.

Although the coefficient of the age variable is insignificant, its positive sign indicates that, mature persons are more likely to repay their loan on time as compared to young people. This is in light with our field survey findings and the odds ratio $[\operatorname{Exp}(B)=1.184]$ which confirms this trend (Table 2).

\section{CONCLUSION AND RECOMMENDATIONS}

During the previous decades, the Cameroonian government began extending credit facilities to farming households in the Far North Region of Cameroon with the sole aim of narrowing the gap between the required and capital available to purchase improved agricultural equipments. Unfortunately, the money borrowed was neither refunded on time nor recovered at all by the microfinance institutions (MFIs) who granted credit. This study was therefore undertaken in order to analyze the determinants of the repayment capacity of credit granted by MFIs to farmers of this region.

The results of the logit model suggest that there are a number of factors which constrained the credit repayment capacity by farmers so as to impact the life of MFIs. From the computed significant coefficients, it would be advisable to grant loan to MFIs members with small household size, with profitable activities, less distant from cash desks, trained for credit management, not married/single, and who use their credit for agricultural practice because they are more likely to refund their credit on time.

However, the model results indicate that the gender, age, farm size, sources of finance, loan size, use of improved technology, do not significantly influence the loan repayment capacity of MFIs' members in this region. Hence, policy makers should give much attention to the significant factors if microfinance services need to be improved in this region.

More precisely, the government should set a system such that: (1) it will be judicial for the rural microfinance development support project (RMDSP) to provide field technicians capable of analyzing the needs of farmers and their credit demands; (2) it will be important to review the repayment schedule of borrowers by taking into consideration the amounts and 
activities, such that lengths of repayment should not be fixed at random; (3) the credit beneficiaries should be well trained on the management and allocation of credit and the proper follow up of MFIs' members should be implemented; (4) it will be important for members of cash desks to demand no more than the amount of credit they really require.

\section{AKNOWLEDGEMENTS}

The authors are grateful to the farmers and members of UCCGN microfinance institutions in the Far North Region, Cameroon for their kindness during the data collection.

\section{REFERENCES}

1. Awunyo-victor, D. 2012. Determinants of loan repayment default among farmers in Ghana. journal of Development and Agricultural Economics , 4 (13): 343-344.

2. Bhatt, N. and Tang, S. Y. 2002. Determinants of Repayment in Microcredit: Evidence from Programs in the United States. International Journal of Urban and Regional Research 26, 360.

3. Gujarati, D.N. 1995. Basic econometrics (third edition). McGraw-Hill: New York, USA.

4. Hunte. 1996. Microfinance and poverty alleviation: case studies of Asia and the Pacific Routledge; USA.

5. IMF, 2012. Czech Republic: Financial System Stability Assessment Update. Country Report $\mathrm{N}^{\circ} 12 / 177$.

6. Ministry of Plan. 2015. Etudes socio-économiques régionales au Cameroun: Provinces du Nord, Extrême-Nord, Adamaoua, Centre, Sud, Est, Ouest, Nord-Ouest, Sud-Ouest et Littoral. Projet PNUD-OPS CMR/98/005/01/2015. Yaoundé, Cameroon, 1420 pp.

7. Muluh, G. A. 1995. Meeting small farmer credit needs in Cameroon: Institutional structures and organizational problems. Ph.D. Dissertation. University of Giessen, Professur für Welternährungswirtschaft, Giessen, Germany, pp.11-12.

8. Nzongang, J. L. D. 2012. Les déterminants des impayés dans les Institutions de Microfinance en zone urbaine : le cas du réseau MUFFA (Mutuelle Financière des Femmes Africaines) au Cameroun. Saving and Development 9 (1): 25-33.

9. Onyeagocha, U.O. and S.A.H. 2012. Determinants of Loan Repayment of Microfinance Institutions in Southeast States of Nigeria. International Journal of Social Science and Humanities 1(1), 6: 4-6.

10. Singh, G., J.S. Sidhu and S. Balawant. 1985. A Study on Repayment Performance of Borrowers in Punjab. Financing Agriculture. New Delhi, India.

11. Teguia, S. J. M. 2015. Analysis of the determinants of formal sources of loan repayment in the Far North Region: A case study of UCCGN. University of Dschang, Faculty of Agronomy and Agricultural Science, $131 \mathrm{pp}$.

12. Terrell, G.R. 1999. Mathematical statistics: a unified introduction. Springer-Verlag: New York, USA.

13. Wooldridge, J.M. 2009. Introductory econometrics: a modern approach. McGraw-Hill: New York, USA.

14. World Bank. 2015. World development indicators database, 2015. http://www.worldbank.org $\left(15^{\text {th }}\right.$ December 2015). 